\title{
Characterization of a novel curcumin analog P1 as potent inhibitor of the NF-KB signaling pathway with distinct mechanisms
}

\author{
Yan-min PENG ${ }^{1}$, Jian-bin ZHENG ${ }^{2}$, Yu-bo ZHOU ${ }^{1, *}$, Jia LI ${ }^{1, *}$ \\ ${ }^{1}$ National Center for Drug Screening, State Key Laboratory of Drug Research, Shanghai Institute of Materia Medica, Chinese Acad- \\ emy of Sciences, Shanghai 201203, China; ${ }^{2}$ School of Pharmacy, East China University of Science and Technology, Shanghai \\ 200237, China
}

Aim: Curcumin has shown promising anticancer activity, which relies on its inhibition on NF-kB pathway. In this study, we characterized the pharmacological profile of a novel curcumin analog $\mathrm{P} 1$ and elucidate the related mechanisms.

Methods: HEK293/NF-KB cells, stably transfected with an NF-kB-responsive luciferase reporter plasmid, were generated for highthroughput screen (HTS). Eight cancer cell lines, including PC3, COLO 205, HeLa cells etc. were tested. Cell viability was assessed using the sulforhodamine B (SRB) assays. Cell apoptosis was evaluated using FACS, immunocytochemistry, and Western blotting. $\mathrm{H}_{2}$-DCFDA and MitoSOX Red were used to detect cellular and mitochondrial reactive oxygen species (ROS). The mitochondrial function was evaluated using mitochondrial oxygen consumption assay.

Results: P1, a tropinone curcumin, was found in HTS targeting the NF-kB pathway. Its $I_{50}$ value in inhibition of TNF- $\alpha-i n d u c e d ~ N F-k B$ activation was $0.8 \mu \mathrm{mol} / \mathrm{L}$, whereas its $\mathrm{IC}_{50}$ values in inhibiting the growth of A549 and HeLa cells were 1.24 and $0.69 \mu \mathrm{mol} / \mathrm{L}$, respectively, which was 20- to 30-fold more potent than curcumin. The inhibition of P1 on the NF-kB pathway was further addressed in HeLa cells. The compound up to $10 \mu \mathrm{mol} / \mathrm{L}$ did not affect the binding of NF-KB to DNA, but markedly inhibited NF-KB nuclear translocation, IKB degradation and IKB kinase phosphorylation. The compound ( 1 and $3 \mu \mathrm{mol} / \mathrm{L}$ ) concentration-dependently induced ROS generation, whereas curcumin up to $20 \mu \mathrm{mol} / \mathrm{L}$ had no effect. P1-induced ROS generation was mainly localized in mitochondria, and reversed by NAC. Moreover, the compound significantly enhanced TNF- $\alpha$-induced apoptosis.

Conclusion: P1 is a novel curcumin analog with potent anticancer activities, which exerts a distinct inhibition on the NF-kB pathway.

Keywords: curcumin; P1; anticancer agent; high-throughput screen; NF-kB; HeLa cell; mitochondria; ROS

Acta Pharmacologica Sinica (2013) 34: 939-950; doi: 10.1038/aps.2013.2; published online 22 Apr 2013

\section{Introduction}

NF-kB represents a group of 5 proteins: c-Rel, RelA (p65), RelB, NF-kB1 (p50 and p105), and NF-kB2 (p52) ${ }^{[1,2]}$. In its inactive state, NF- $\mathrm{kB}$ is sequestered in the cytoplasm as a heterotrimer consisting of $\mathrm{p} 50, \mathrm{IK}_{\mathrm{K}} \mathrm{B}$, and p65, which is the most common form of NF-kB. Upon activation, IkBa undergoes phosphorylation and ubiquitination-dependent degradation, causing p65 to translocate to the nucleus and bind to a specific consensus sequence in the DNA, which results in downstream gene transcription. NF-kB activates at least 150 genes, including antiapoptotic genes (eg, Bcl-xL, cIAP, survivin, and cFLIP), COX-2,

\footnotetext{
* To whom correspondence should be addressed.

E-mail jli@mail.shcnc.ac.cn (Jia LI); ybzhou@mail.shcnc.ac.cn (Yu-bo ZHOU)

Received 2012-10-22 Accepted 2013-01-10
}

matrix metalloproteinase 9 (MMP-9), genes encoding adhesion molecules, chemokines, and inflammatory cytokines and cell cycle regulatory genes $(e g \text {, cyclin D1 and } c-m y c)^{[3]}$. Aberrant activation of the NF-KB pathway is involved in the pathogenesis of many human diseases, such as cancer, diabetes, asthma, stroke, atherosclerosis, arthritis, inflammatory bowel disease, viral infections, etc ${ }^{[4]}$. NF- $\mathrm{kB}$ is also a critically important cell survival factor that protects many different types of cells from apoptosis ${ }^{[5,6]}$. There is increasing evidence that NF- $\mathrm{KB}$ may play an important role in cancer. Thus, an inhibitor of the NF- $\mathrm{kB}$ pathway is promising for the prevention and treatment of cancer.

Tumor necrosis factor-alpha (TNF-a), a key pro-inflammatory factor, has shown anti-tumor activity in several preclinical models and non-comparative clinical trials ${ }^{[7-9]}$. However, its use as a therapy is not ideal due to its systemic cytotoxic- 
ity and the resistance of tumor cells ${ }^{[10]}$. Recent studies have shown that the abnormal activation of NF- $\mathrm{KB}$ is the main reason for TNF-a tolerance in many types of tumors ${ }^{[7,10]}$. Upon binding to its receptor (tumor necrosis factor receptor, TNFR), TNF-a may induce apoptosis by recruiting tumor necrosis factor receptor type 1-associated DEATH domain protein (TRADD), Fas-associated death domain protein (FADD), and caspase-8, for example, to activate apoptotic programs. However, the bound receptor TNFR has the ability to activate IKK, which in turn results in the activation of the NF-kB pathway. Therefore, agents that suppress TNF- $\alpha$-induced NF-kB activation and simultaneously enhance TNF-a-induced apoptotic activation will significantly improve the anti-tumor activities of TNF-a.

The polyphenol curcumin is the active ingredient in the herbal remedy and dietary spice turmeric (Curcuma longa Linn $)^{[11]}$ and possesses antioxidant ${ }^{[12,13]}$, anti-inflammatory ${ }^{[14,15]}$, anti-carcinogenic ${ }^{[16,17]}$, and chemopreventive ${ }^{[18]}$ activities in various tumor cells. It has been reported that the anti-cancer activity of curcumin ${ }^{[19,20]}$ and its analogs ${ }^{[21,22]}$ relies on the inhibition of the NF-kB pathway. Curcumin inhibits the proliferation of many cancer cells in vitro and in vivo ${ }^{[23]}$. A phase II trial indicated that chronic oral administration of curcumin had limited clinical benefits due to its low bioavailability ${ }^{[24]}$. We report here the identification of $\mathrm{P} 1$, a tropinone curcumin analog and a novel NF-kB inhibitor and apoptosis inducer. P1 exhibited a 20-fold higher ability to suppress tumor cell growth and the NF-KB pathway compared with curcumin. The results presented here may indicate a potential candidate for anti-cancer therapy.

\section{Materials and methods}

\section{Chemicals and reagents}

P1 was obtained from Specs (Delft, The Netherlands). TNFa, NAC, carbonyl cyanide $m$-chlorophenylhydrazone (CCCP), and 5,5',6,6' 'tetrachloro-1,1',3,3' -tetraethyl-imidacarbocyanineiodide (JC-1) were obtained from Sigma Aldrich (St Louis, MO, USA). Curcumin was obtained from Aladdin (Shanghai, China). The IKK- $\beta$ wild type plasmid (plasmid 11103) was purchased from Addgene (Cambridge, MA, USA), and DNA with the mutated cysteine residue 179 (Cys179A) was prepared using the QuikChange site-directed mutagenesis kit (Stratagene, La Jolla, CA, USA).

\section{Cell Lines}

HEK293/NF-KB cells, which are HEK293 cells stably transfected with an NF-kB-responsive luciferase reporter plasmid, were generated. Other cells were purchased from Cell Bank (Chinese Academy of Sciences, Shanghai, China).

\section{Construction of NF-KB stable cell lines}

A luciferase reporter plasmid containing an NF- $\mathrm{kB}$ binding site and pcDNA3.1 were co-transfected into HEK293 cells using Lipofectamine 2000 at a concentration of 10:1 (Invitrogen, Carlsbad, CA, USA). Stable recombinant cells were selected for resistance to $1 \mathrm{mg} / \mathrm{mL}$ G418 and for a strong luciferase signal.

\section{HTS assay}

Stable HEK293/NF-кB cells were plated into 384-well plates at a concentration of approximately 3000 cells per well. After culture overnight, compounds were added to the medium at a final concentration of $2 \mu \mathrm{g} / \mathrm{mL}$. After $6 \mathrm{~h}$, the luciferase substrate was added to each well, and the released luciferin signal was detected using an EnVision microplate reader.

\section{Luciferase assay}

HEK293/NF-KB cells were seeded into 96-well cell culture plates (Corning, NY, USA) and allowed to grow for $24 \mathrm{~h}$. The cells were then treated with compounds, followed by stimulation with TNF-a. Luciferase activity was determined using luciferase assay kits (Promega, Madison, WI, USA) according to the manufacturer's instructions.

\section{Isolation of total RNA and reverse transcription-PCR}

Total RNA was extracted from cells using TRIzol reagent (Invitrogen). Complementary DNA generated by M-MLV reverse transcriptase (Promega) was analyzed by quantitative PCR using SYBR ${ }^{\circledR}$ Premix Ex Taq ${ }^{\mathrm{TM}}$ (TaKaRa, Dalian, China). All samples were run in duplicate and normalized to tubulin expression.

\section{Antibodies and immunoblotting analysis}

Anti-phospho-IKK-a (Ser176/Ser180)/IKK- $\beta$ (Ser177/Ser181), anti-IKK- $\beta$, anti-IKB- $\alpha$, anti-phospho-p38 MAPK (T180/Y182), anti-p65, anti-phospho-p65 (Ser536), anti-p38 MAPK, and antiPARP antibodies were purchased from Cell Signaling Technology (Boston, Massachusetts, USA). All antibodies were used as recommended by the manufacturers. Cell lysates were subjected to electrophoresis on $8 \%$ SDS-PAGE gels and blotted with the indicated antibodies.

\section{IKK- $\beta$ kinase assay}

Human His-tagged IKK- $\beta$ protein was expressed in High5 insect cells using a baculovirus expression system and purified using Ni-NTA (QIAGEN, Valencia, CA, USA). IKK- $\beta$ in vitro kinase activity was measured using $Z^{\prime}$-LYTE kinase assay kits according to the manufacturer's instructions (Invitrogen).

\section{Assessment of apoptosis}

P1-induced apoptosis was determined using an Annexin V-FITC Apoptosis Detection kit (KeyGen, Nanjing, China). Briefly, HeLa cells were harvested after treatment with P1 for $24 \mathrm{~h}$. The cells were washed twice with cold PBS and resuspended in binding buffer. Cells were then stained with Annexin V-FITC and propidium iodide and analyzed with a FACScan flow cytometer (Becton Dickinson, Sparks, Maryland, USA).

\section{Immunocytochemistry}

Immunocytochemistry was performed as previously described $^{[25]}$. Images were captured with an Olympus DP72 
digital camera (Melville, NY, USA).

\section{Electrophoretic mobility shift assay}

Electrophoretic mobility shift assays (EMSA) were performed using a LightShift Chemiluminescent Electrophoretic Mobility Shift Assay kit (Thermo Scientific, Waltham, MA, USA) according to the manufacturer's instructions. Briefly, HeLa cells were treated with $30 \mathrm{ng} / \mathrm{mL}$ TNF-a for $15 \mathrm{~min}$ before nuclear protein preparation. Binding was assayed in $20 \mu \mathrm{L}$ of solution by incubating $10 \mu \mathrm{g}$ of nuclear extract with $40 \mathrm{fmol}$ of a biotin-labeled NF-кB DNA probe in the presence or absence of P1. The complex was separated on a $6.5 \%$ nondenaturing polyacrylamide gel.

\section{Cell proliferation assay}

SRB proliferation activity assays were measured using a SpectraMax 340 microplate reader (Molecular Devices, Sunnyvale, CA) as previously described ${ }^{[26]}$. $\mathrm{IC}_{50}$ values were derived from a nonlinear regression model (curvefit) based on a sigmoidal dose response curve (variable slope) and computed using Graphpad Prism version 5.02 (Graphpad Software).

\section{ROS measurement}

ROS in vitro production was monitored using $\mathrm{H}_{2}$-DCFDA (Invitrogen). The $100 \mu \mathrm{L}$ assay system contained $10 \mu \mathrm{mol} / \mathrm{L}$ $\mathrm{H}_{2}$-DCFDA, $2 \mu \mathrm{L}$ of compound, and $2 \mathrm{mmol} / \mathrm{L}$ DTT. Oxidation of the probe was detected by monitoring the increase in fluorescence with Envision at $490 \mathrm{~nm}$ excitation and $525 \mathrm{~nm}$ emission.

The levels of intracellular ROS and mitochondrial ROS were measured by $\mathrm{H}_{2}$-DCFDA and Mito-Sox (Invitrogen), respectively, according to the manufacturer's instructions. Briefly, cells were treated for the indicated time period, washed with PBS, and then incubated for 30 min with $\mathrm{H}_{2}$-DCFDA or MitoSOX. Cells were then washed and collected with PBS, and fluorescence was measured using a FACS flow cytometer (Becton Dickinson, San Diego, CA, USA).

\section{Mitochondrial membrane potential assay}

Mitochondrial membrane potential assays were based on a previous report ${ }^{[27]}$. Briefly, HeLa cells were treated with P1 for $40 \mathrm{~min}$ before being stained with $0.1 \%$ JC-1 for another $20 \mathrm{~min}$. The ratio of red to green fluorescence reflects the $\Delta \psi \mathrm{m}$.

\section{SOD assay}

Briefly, HeLa cells were harvested after exposure to compounds. The cells were washed twice and then resuspended in PBS. The SOD activity was measured using an SOD Assay Kit (Njjcbio, Nanjing, China).

\section{Preparation of cytosolic and nuclear fractions}

HeLa cells were collected by centrifugation after incubation with compounds for the period indicated in the text. The cells were lysed, and the cytosolic and nuclear fractions of cells were prepared as described previously ${ }^{[28]}$.

\section{Mitochondria isolation and respiration measurement}

Mitochondria were isolated from HeLa cells using a previously described method ${ }^{[29]}$. Respiration in isolated mitochondria was measured with a Clark-type oxygen electrode (Strathkelvin Instruments Ltd Glasgow, Scotland). A standard respiration medium was used. Mitochondria were transferred to the electrode chamber, and following attainment of a steady rate of oxygen consumption, P1 was added at increasing doses, and its effect on oxygen consumption was recorded.

\section{Statistical analysis}

Each experiment was performed three times. The values shown are the mean \pm SD. Student's $t$-test (two-sided) was used to test for significant differences between groups.

\section{Results}

$\mathrm{P} 1$, a novel tropinone curcumin analog, was identified as a NF-KB inhibitor by HTS

A HEK293 stable cell line containing a luciferase expression construct driven by NF-кB binding activity was created, and the luciferase reporter assay was optimized for use in automated HTS. From the screening of a library containing 40000 pure, synthetic compounds in the National Center for Drug Screening (NCDS), P1 was identified. P1 has a conjugated $\alpha, \beta-$ unsaturated ketone moiety, which is the core structure of curcumin, and is very similar to EF-24 (Figure 1).
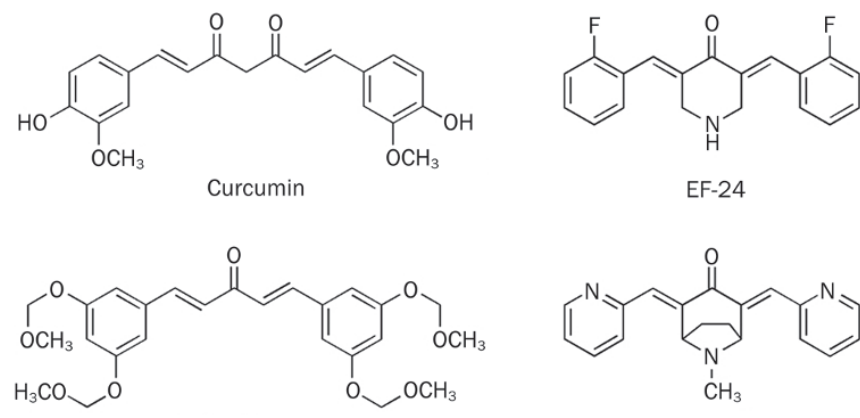

GO-Y030

P1

Figure 1. Chemical structures of curcumin, GO-Y030, EF-2, and P1.

\section{P1 inhibited cancer cell growth and induced apoptosis}

The NF-kB transcription factors control various processes of cancer, such as invasion, angiogenesis, growth, and metastasis. Therefore, blocking the NF-kB pathway may inhibit cell survival signals and induce apoptosis ${ }^{[30]}$. As expected, P1 inhibited cancer cell growth in a panel of tumor cell lines (Figure 2A), with the best $\mathrm{IC}_{50}$ of $0.28 \mu \mathrm{mol} / \mathrm{L}$. Additionally, this suppressive effect on cell growth was compared with that of curcumin. In A549 and HeLa cells, the $\mathrm{IC}_{50}$ values for curcumin were $17.02 \mu \mathrm{mol} / \mathrm{L}$ and $11.99 \mu \mathrm{mol} / \mathrm{L}$, respectively, whereas those for P1 were $1.24 \mu \mathrm{mol} / \mathrm{L}$ and $0.69 \mu \mathrm{mol} / \mathrm{L}$, respectively. We next examined whether P1 induced apop- 
tosis in tumor cells. As shown by DAPI staining, P1 induced chromatin condensation in a concentration-dependent manner in HeLa cells (Figure 2B). Similar results were obtained from Annexin V-FITC staining (Figure 2C), in which treatment with $3 \mu \mathrm{mol} / \mathrm{L}$ P1 for $24 \mathrm{~h}$ induced apoptosis in $72.65 \%$ of the cells. It is well known that the proteolysis of poly (ADP-ribose) polymerase (PARP) by caspase-3 is an early event or prerequisite for the execution of caspase-dependent apoptosis. As shown in Figure 2D, P1 significantly triggered the cleavage of PARP, further confirming that P1 induced apoptosis in HeLa cells.

NF-kB regulates a wide variety of genes that encode antiapoptotic proteins, cell cycle regulators, cytokines, and proteins involved in cell-cell and cell-extracellular matrix interactions. We next examined the effects of P1 on NF-kBdependent gene expression in HeLa cells. As shown in Figure 2E, P1 suppressed the expression of the anti-apoptosis gene
$\mathrm{Bcl}-2$, the anti-proliferation genes COX-2 and Cyclin B1, and the anti-angiogenesis gene MMP-9 in a concentration-dependent manner.

\section{P1 inhibited the NF-KB pathway in a dose- and time-dependent} manner

In HEK293/NF-KB cells, curcumin inhibited the TNF-ainduced expression of the NF-kB-responsive promoter reporter gene in a dose-dependent manner, with an $\mathrm{IC}_{50}=21 \mu \mathrm{mol} / \mathrm{L}$ (Figure 3A). However, P1 exhibited a much stronger activity than curcumin, and its $\mathrm{IC}_{50}$ value reached $0.8 \mu \mathrm{mol} / \mathrm{L}$ (Figure 3B). Furthermore, $1 \mu \mathrm{mol} / \mathrm{L}$ P1 also inhibited the NF-kBresponsive promoter reporter gene in a time-dependent manner (Figure 3C). In all of the above experiments, the cell number was detected in parallel with the expression of the reporter gene to exclude false positives in which luciferase activity was suppressed by cell death (Figure 3A-3C). The direct effect of
A

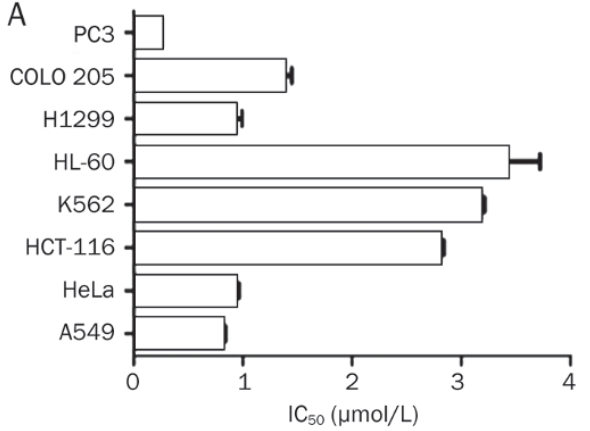

B

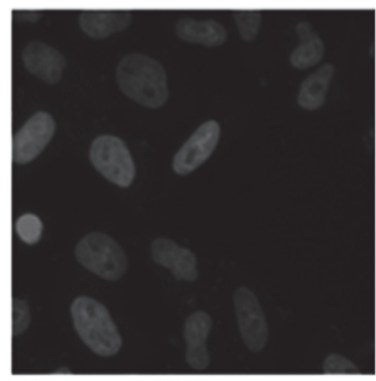

$\mathrm{P} 1,1 \mu \mathrm{mol} / \mathrm{L}$

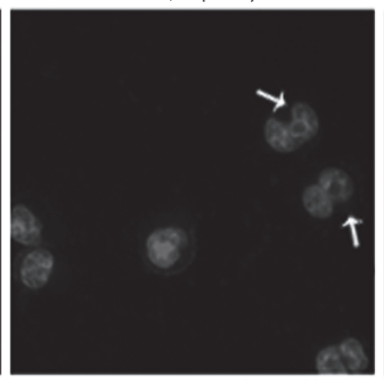

$\mathrm{P} 1,3 \mu \mathrm{mol} / \mathrm{L}$

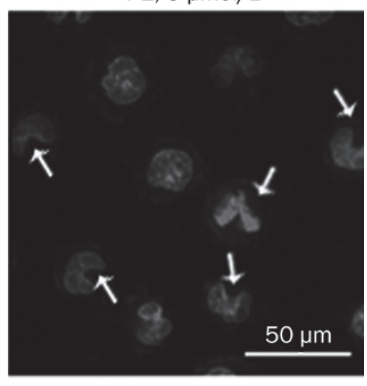

C
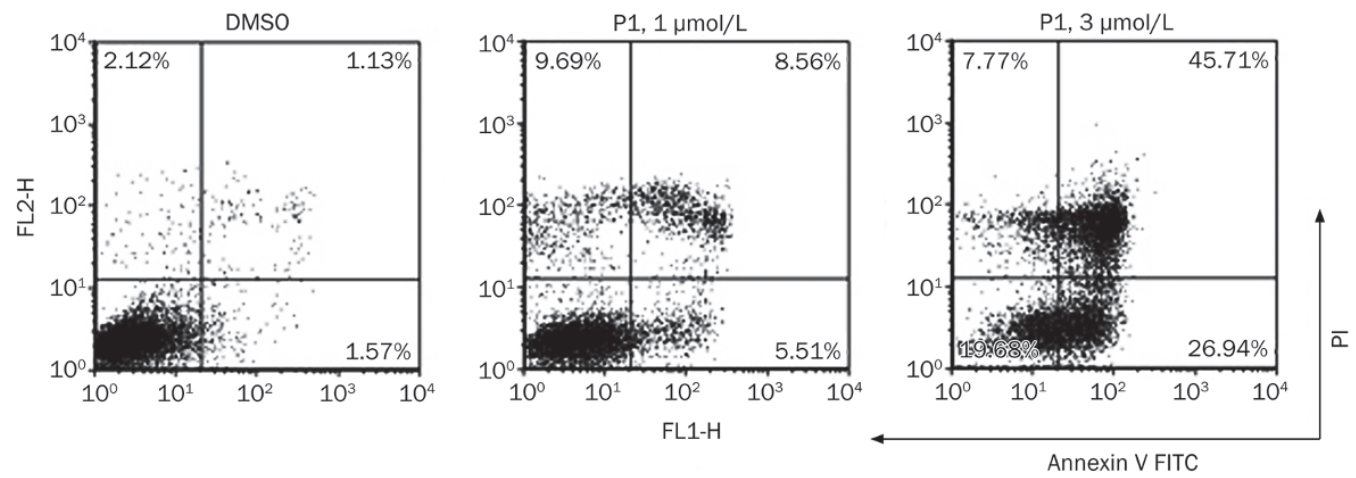

D
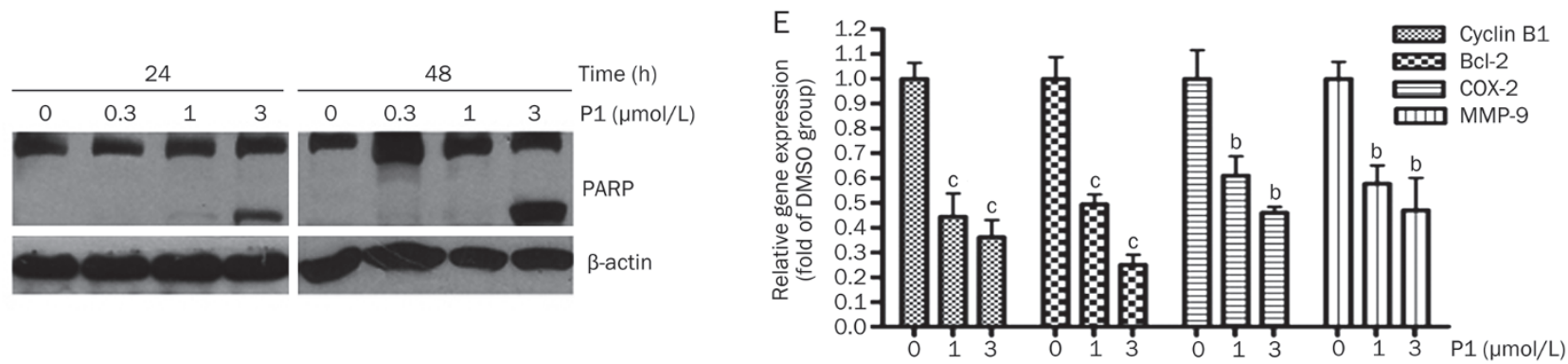

Figure 2. $P 1$ induced apoptotic cell death. (A) IC $C_{50}$ of $P 1$ in eight different cancer cell lines. SRB assay was conducted after $72 \mathrm{~h}$ of treatment. (B) DAPI staining of HeLa cells after P1 treatment for $24 \mathrm{~h}$. (C) Annexin V-FITC staining of HeLa cells after P1 treatment for $24 \mathrm{~h}$. (D) PARP cleavage induced by P1 after treatment for the indicated times. (E) The effect of P1 on expression of NF-kB-regulated genes in HeLa cells after treatment for $12 \mathrm{~h}$. Mean \pm SD. $n=3 .{ }^{b} P<0.05,{ }^{c} P<0.01$ vs the control. 

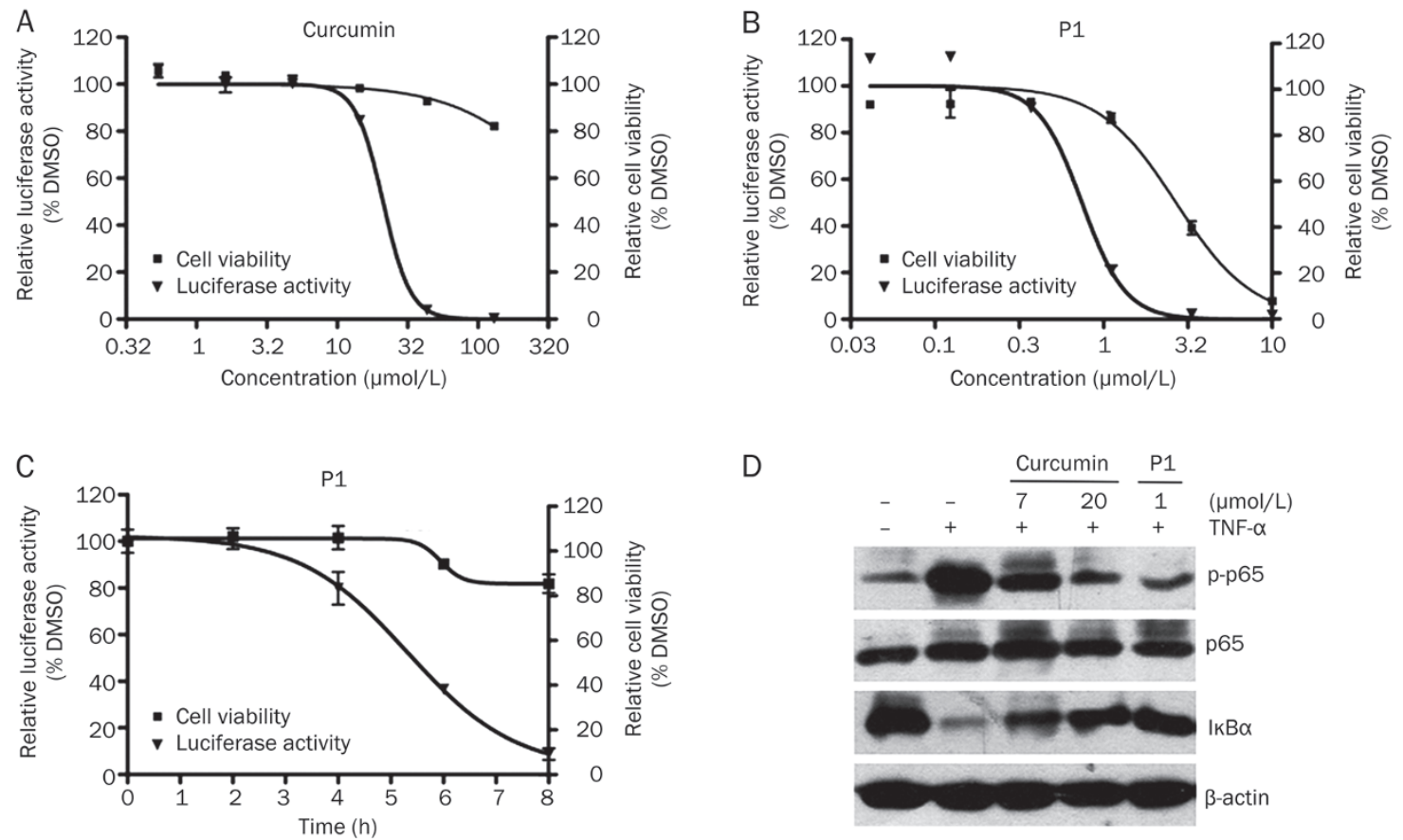

D

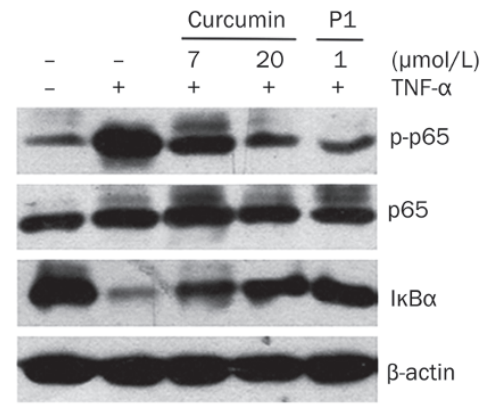

Figure 3. $\mathrm{P} 1$ exhibited stronger inhibition of the NF-kB signaling pathway than curcumin. (A) The inhibition curve of curcumin on TNF- $\alpha$ (10 ng/mL)induced NF-KB luciferase activity. Cell viability was examined in parallel with luciferase activity. (B) Dose dependence curve of P1 inhibition of TNF- $\alpha$ induced NF-KB luciferase activity. Cell viability was examined in parallel with luciferase activity. (C) Time dependence curve of P1 inhibition of TNF- $\alpha$ induced NF-KB luciferase activity. Cell viability was examined in parallel with luciferase activity. (D) Western blot analysis of the key proteins in the NF$\mathrm{kB}$ pathway after curcumin or $\mathrm{P} 1$ treatment for $6 \mathrm{~h}$. Mean \pm SD. $n=3$

P1 on firefly luciferase was also investigated, and P1 exhibited no effect on enzyme activity (data not shown).

The inhibitory effects of curcumin and P1 on NF-kB pathway activation was also examined by Western blotting. The result indicates that the inhibitory potency of $1 \mu \mathrm{mol} / \mathrm{L}$ P1 was comparable with that of $20 \mu \mathrm{mol} / \mathrm{L}$ curcumin (Figure 3D).

\section{P1 did not affect NF-KB DNA binding but did inhibit p65 nuclear translocation and phosphorylation}

To understand the mechanism of P1 inhibition of NF-kB, the effect of P1 on NF-kB DNA binding and NF-kB nuclear translocation was examined using electrophoretic mobility shift assays, immunoblotting, and immunofluorescence analyses. The TNF- $\alpha$-induced classic NF-kB pathway results in the activation and nuclear translocation of NF-kB dimers. Our results showed that P1 did not inhibit the DNA-binding ability of NF-kB dimers in vitro (Figure $4 \mathrm{~A}$ ). Treatment with $3 \mu \mathrm{mol} / \mathrm{L}$ P1 for $6 \mathrm{~h}$ significantly inhibited the translocation of p65 from the cytosol to the nucleus (Figure 4B). Western blot analysis of p65 in nuclear extracts further confirmed that p65 activation by TNF-a and translocation into the nucleus was almost fully blocked by P1 (Figure 4C). P1 also inhibited the TNF-ainduced phosphorylation of p65 on Ser536, which is phosphorylated by IKK- $\beta$ and needed for its transcriptional activity (Figure 4D). These results imply that P1 may have interfered with the molecular events upstream of p65 translocation and phosphorylation.

\section{P1 inhibited TNF- $\alpha$-induced IкB $\alpha$ phosphorylation and degrada- tion}

The activation and nuclear translocation of $\mathrm{NF}-\mathrm{KB}$ require the phosphorylation, ubiquitination, and degradation of IкBa. We next examined whether P1 inhibited the TNF-a-induced phosphorylation and degradation of IkBa. As shown in Figure 4D, treatment with P1 for $6 \mathrm{~h}$ inhibited the TNF-a-induced phosphorylation and degradation of IкBa in a dose-dependent manner and showed a significant effect at a concentration similar to that used to inhibit the TNF-a-induced luciferase gene reporter activity.

\section{P1 inhibited TNF- $\alpha$-induced $p 65$ and IKK- $\beta$ phosphorylation}

IKK- $\beta$ is the major upstream kinase of IKBa in the canonical NF-KB signaling pathway. Activation of IKK- $\beta$ requires the phosphorylation of Ser177/Ser181 on its active loop. The curcumin analogs GO-Y030 and EF-24 have both been shown to inhibit IKK- $\beta$ activity directly ${ }^{[31,32]}$. Interestingly, however, P1 did not inhibit IKK- $\beta$ activity in vitro (Figure $4 \mathrm{E}$ ). The phosphorylation of IKK- $\beta$ in HeLa cells was then examined after treatment with P1 for $6 \mathrm{~h}$. As shown in Figure 4D, P1 inhibited the TNF- $\alpha$-induced phosphorylation of IKK- $\beta$ in a dosedependent manner. The effect of P1 on the IL-1 $\beta$-induced phosphorylation of IKK- $\beta$ was also examined, and a similar result was obtained (data not shown).

Next, the specificity of the effect of P1 on TNF-induced NF- $\mathrm{KB}$ activation was investigated. We found that TNF- $\mathrm{a}$ acti- 
A

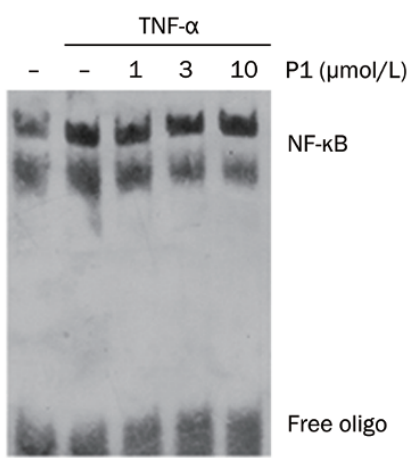

B
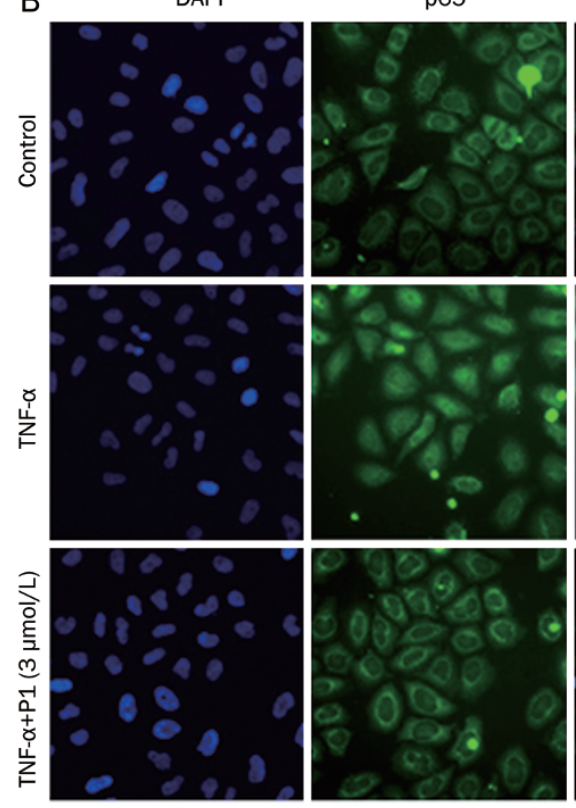

\section{E}

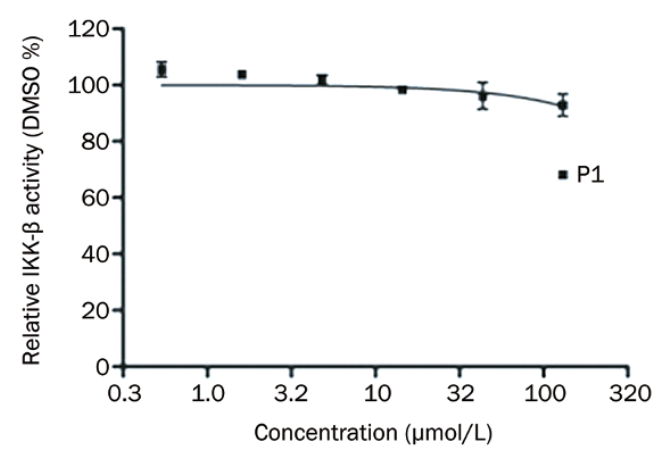

C

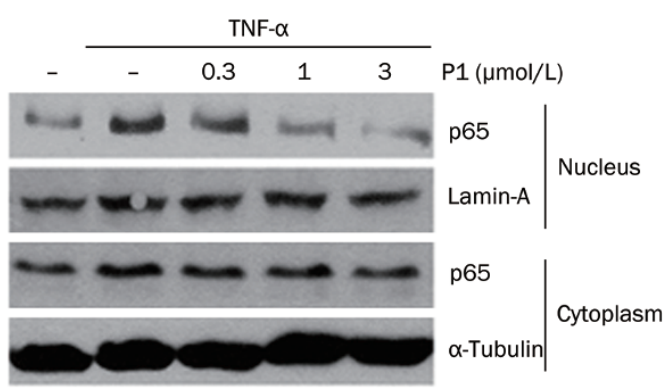

D
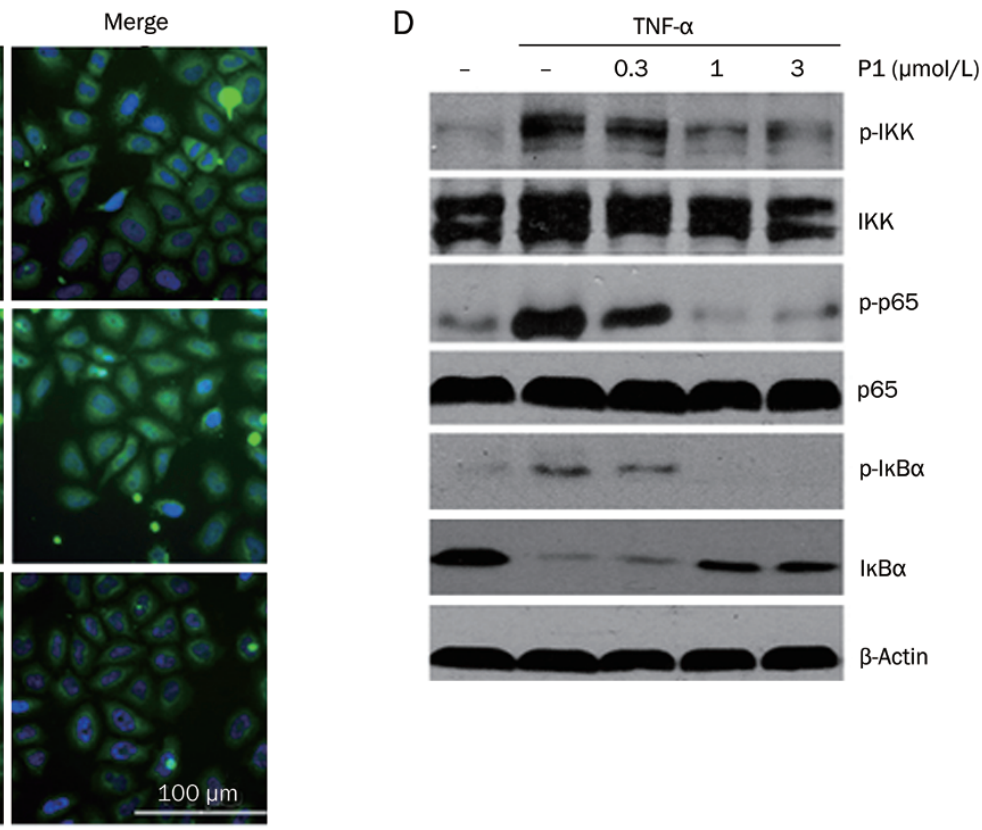

$\mathrm{F}$
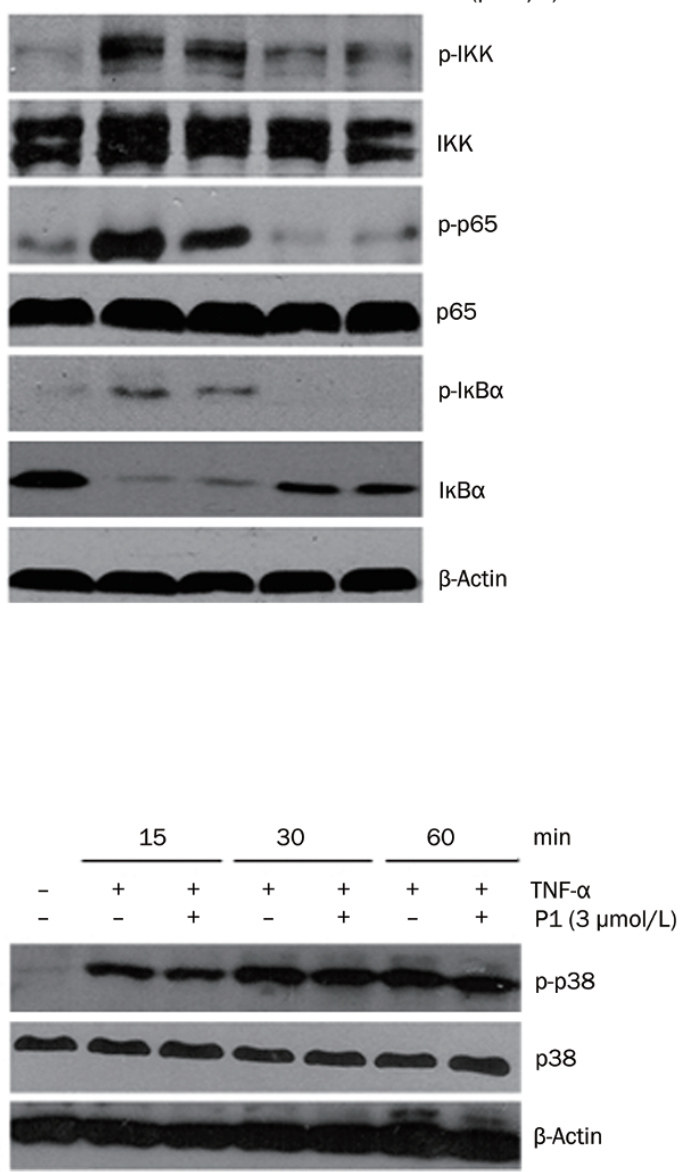

Figure 4. Effects of P1 on the inhibition of the NF-KB signaling pathway. (A) EMSA analysis of NF-KB DNA-binding activity in vitro. (B) Immunofluorescence analysis of p65 nuclear translocation in HeLa cells. Cells were pretreated with DMSO or P1 for $6 \mathrm{~h}$ and then stimulated with or without TNF- $\alpha$. (C) HeLa cells were pretreated with P1 for $6 \mathrm{~h}$ and then stimulated with TNF- $\alpha$ for 30 min. Nuclear proteins were prepared for Western blot analysis. (D) Western blot analysis of the NF-KB signaling pathway in HeLa cells after treatment with P1 for 6 h. (E) The effect of P1 on IKK- $\beta$ activity in vitro. (F) The effect of P1 on TNF- $\alpha$-induced p38 activation after treatment for $6 \mathrm{~h}$.

vated p38 MAPK in a time-dependent manner, but P1 had no effect on its activation (Figure $4 \mathrm{~F}$ ), indicating that the effect of $\mathrm{P} 1$ on IKK- $\beta$ activation is specific.
The NF-KB inhibition induced by P1 was a downstream effect of reactive oxygen species

As reported previously, the inhibition of the NF-kB signaling 
pathway by curcumin is attributed to anti-oxidation ${ }^{[12,13]}$, and EF-24 also suppresses cellular ROS. The effect of P1 on cellular ROS was tested using H2-DCFDA staining. Surprisingly, $\mathrm{P} 1$ induced ROS generation in a dose-dependent manner; however, $20 \mu \mathrm{mol} / \mathrm{L}$ curcumin had no observable effect on cellular ROS in HeLa cells (Figure 5A). Next, the dependence of the NF-kB activation inhibited by P1 on ROS was examined. P1-induced NF-KB inhibition was blocked by the presence of NAC, a ROS scavenger, as shown by luciferase assay and western blot (Figure 5B, 5C). Additionally, curcumin did not act through the same mechanism, as NAC had no effect on curcumin-induced NF-KB inhibition (Figure 5B). The role of ROS in the anti-cancer activity of P1 was also examined. As shown in Figure 5D and 5E, P1-induced cell death and apoptosis were both significantly reduced by NAC in HeLa cells. These results suggest that $\mathrm{P} 1$, unlike curcumin, induced ROS generation, which played a role in the inhibition of the NF-kB signaling pathway and cell growth.

IKK- $\beta$ contains a cysteine at position 179 in its activation loop that is critical for its biological activity and is sensitive to cellular oxidative stress and redox environment. To determine whether this cysteine is involved in P1-induced NF-KB inhibition, HeLa cells were transfected with empty vector, wild-type IKK- $\beta$, or IKK- $\beta$ with a C179A mutation. The transfection of wild-type IKK- $\beta$ did not affect the ability of P1 to inhibit NF-KB activity (Figure 5F). In contrast, P1 had only a minor effect on NF-KB activity when transfected with IKK- $\beta$ (C179A) (Figure 5F). These findings imply that P1 inhibited IKK- $\beta$ activity through modification of the Cys179 residue.

\section{P1 induced ROS in mitochondria}

ROS generation has been reported to occur primarily in mitochondria ${ }^{[33]}$, and we wondered whether P1 acted directly on mitochondria. Mitochondrial ROS were measured using MitoSOX staining, which was increased in a dose-dependent manner after $3 \mathrm{~h}$ of treatment with P1 (Figure 6A). The ROS measured by MitoSOX were comparable with those of $\mathrm{H}_{2}$-DCFDA, which indicates that the ROS generated by P1 were mainly localized in the mitochondria. Mitochondrial membrane potential (MMP), which is an index of mitochondrial function, was also examined. MMP was reduced by $\mathrm{P} 1$ in HeLa cells (Figure 6B). Although most ROS inducers generate ROS at a cellular level, several compounds generated free radicals in vitro. As shown in Figure $6 \mathrm{C}$, a strong ROS signal was detected in the presence of $2 \mu \mathrm{mol} / \mathrm{L}$ of an isoquinoline1,3,4-trione derivative ${ }^{[27]}$ in vitro, but no noticeable ROS signal change was detected in the presence of P1. Based on these results, P1 induced ROS by affecting mitochondrial function. To determine whether there was a specific inhibition of mitochondrial complex function, HeLa cell mitochondria were isolated, and the effect of P1 on ADP-stimulated respiration in the presence of complex I (glutamate) or complex II (succinate) substrates was examined. P1 did not inhibit mitochondrial respiration with either substrate (Figure 6D). To determine whether P1 had any effect on the ROS elimination system, SOD activity in HeLa cells was tested after treatment with P1 for $3 \mathrm{~h}$ (Figure 6E). P1 had no effect on SOD activity.

\section{P1 stimulated apoptosis induced by TNF- $\alpha$}

Because the activation of NF-KB has been shown to inhibit the apoptosis induced by TNF- $\alpha$, the inhibition of NF-KB activation by pharmacological approaches has become an attractive strategy for improving the anti-tumor activity of TNF-a ${ }^{[10,34]}$. The effect of P1 in combination with TNF-a on cancer cell apoptosis was evaluated using DAPI staining, Annexin V staining, and PARP cleavage. A treatment of $1 \mu \mathrm{mol} / \mathrm{L}$ P1 was used in the subsequent experiment, as it induced moderate apoptosis after $24 \mathrm{~h}$ in HeLa cells. DAPI staining showed that, in the presence of TNF- $a$, which showed weak pro-apoptotic activity, the addition of $\mathrm{P} 1$ induced substantially more apoptosis (Figure 7A). A similar result was obtained by Annexin V-FITC staining (Figure 7B). Furthermore, P1 stimulated the TNF-a-induced cleavage of PARP in HeLa cells in a timedependent manner (Figure 7C). Taken together, the above results suggest a synergistic effect of P1 and TNF-a in inducing apoptosis, implying a potential role in anti-cancer therapy.

\section{Discussion}

The NF-KB signaling pathway has proven to be a treasure trove for cancer drug development ${ }^{[35]}$. We developed an HTS system that detected NF-кB DNA-binding activity; thus, compounds acting on any part of the NF-KB signaling pathway could be identified. Here, we reported that P1, a curcumin analog, was a potent NF-KB inhibitor, showing more remarkable anti-cancer activity than curcumin in vitro. The inhibition of NF-KB and cell growth by P1 was found to be 20- to 30 -fold greater than that caused by curcumin, which suffered from low bioavailability. The NF-kB inhibition mechanism of $\mathrm{P} 1$ was investigated in detail. P1 did not directly affect the binding of NF-KB to DNA but inhibited NF-KB nuclear translocation, IкB degradation and IKK phosphorylation and also downregulated the expression levels of NF-KB-mediated genes involved in proliferation, apoptosis, invasion, and angiogenesis. Finally, we presented evidence that mitochondrial ROS generation was involved in NF-kB inhibition.

Much work has been performed to improve the natural anti-cancer effects and pharmacological profile of curcumin. Ordinarily, the conjugated $\alpha, \beta$-unsaturated ketone moieties are retained in successful anti-cancer compounds based on curcuminoid structures, such as the monoketone curcumin analogs GO-Y030 and EF24 (Figure 1), which has a similar structure to P1. Both of these monoketone curcumin analogs exhibit increased activity compared with curcumin and potently suppress the NF-KB signaling pathway, at least partially through direct action on IKK $\beta^{[36,37]}$. However, P1 did not directly inhibit the kinase activity of IKK $\beta$ even at $100 \mu \mathrm{mol} / \mathrm{L}$, compared with the reported $\mathrm{IC}_{50}$ of $1.9 \mu \mathrm{mol} / \mathrm{L}$ for EF-24 and $0.9 \mu \mathrm{mol} / \mathrm{L}$ for GO-Y030 against IKK $\beta$. It is worth further study to determine the reason why these compounds with similar structures differ in their mechanisms.

Curcumin is efficacious against colon cancer, cystic fibrosis, and a variety of other disorders. The results of a Phase II 
A

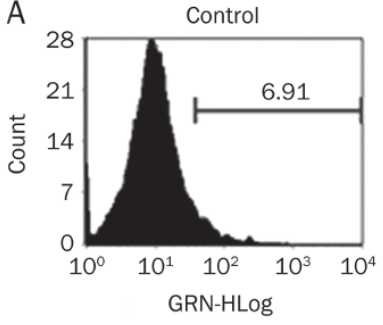

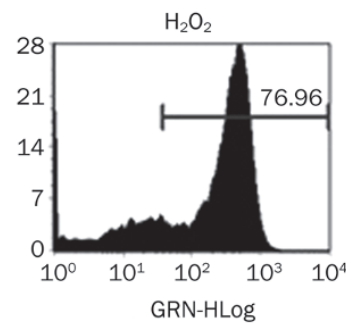
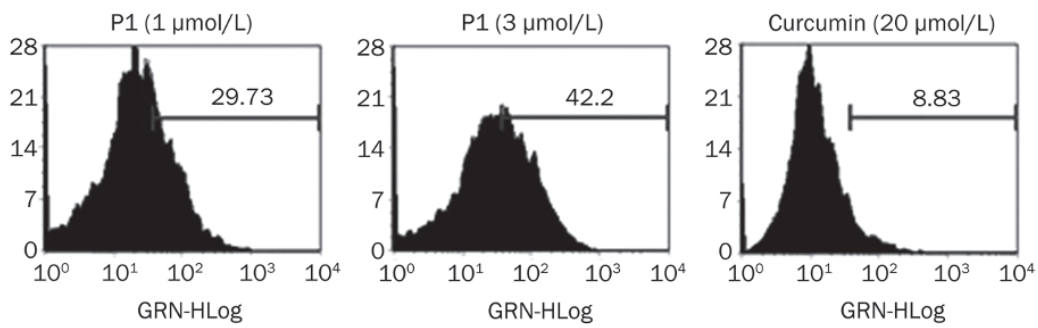

B
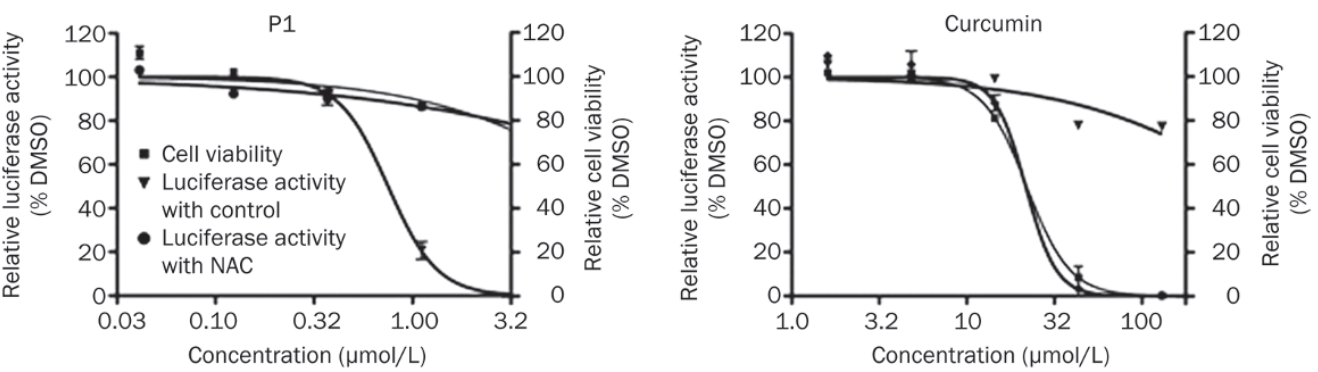

C

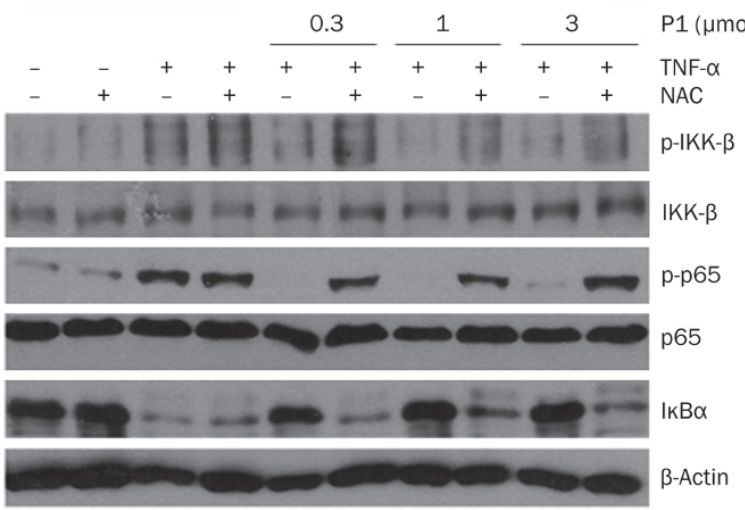

D

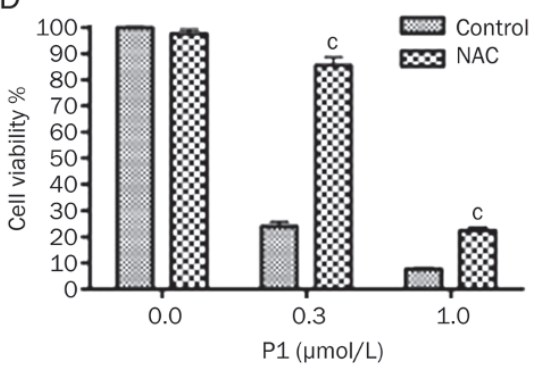

E
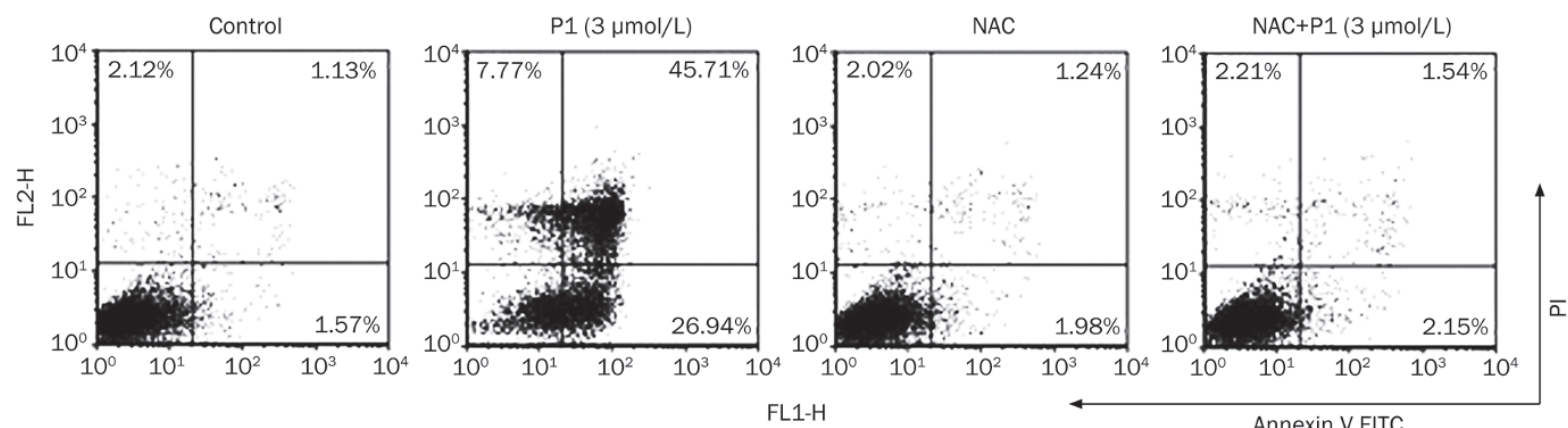

$\mathrm{F}$

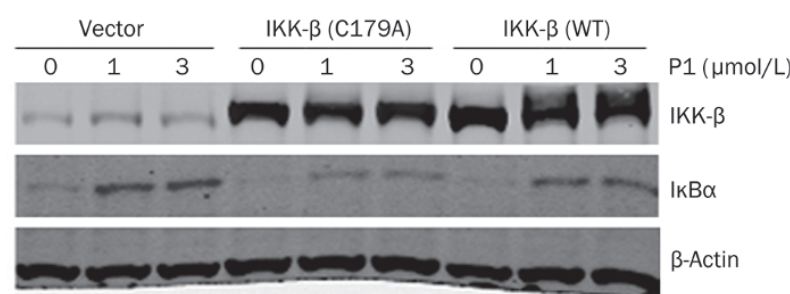

Figure 5. P1 inhibited NF-KB by inducing cellular ROS. (A) The generation of ROS induced by $\mathrm{P} 1$ or $\mathrm{H}_{2} \mathrm{O}_{2}(100 \mu \mathrm{mol} / \mathrm{L})$ in HeLa cells after treatment for $3 \mathrm{~h}$ was detected by $\mathrm{H}_{2}$-DCFDA staining. (B) NF-KB luciferase activity was affected by P1 or curcumin, with or without NAC (10 mmol/L), after treatment for $6 \mathrm{~h}$. Cell viability was examined in parallel with luciferase activity. (C) The effect of NAC on P1-induced NF-kB inhibition after $6 \mathrm{~h}$ of treatment in HeLa cells. (D) The effect of NAC on P1-induced HeLa cell death. Growth-inhibitory effects were assessed after $72 \mathrm{~h}$ of treatment. (E) The effect of NAC on P1-induced HeLa cell apoptosis. FACS analysis was conducted after $24 \mathrm{~h}$ of treatment. (F) The effect of IKK- $\beta$ C179A mutation on P1-induced NF-KB inhibition after $6 \mathrm{~h}$ of treatment. Mean \pm SD. $n=3 .{ }^{\mathrm{b}} P<0.05,{ }^{\mathrm{c}} P<0.01$ vs the control. 
A

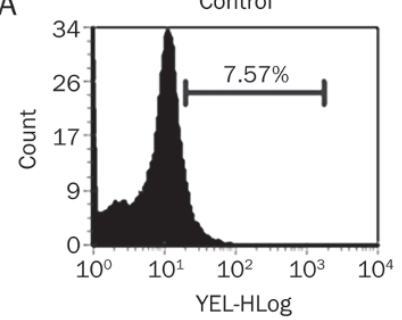

B

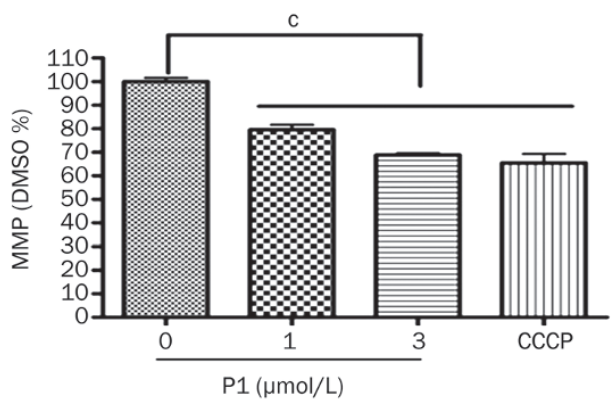

D

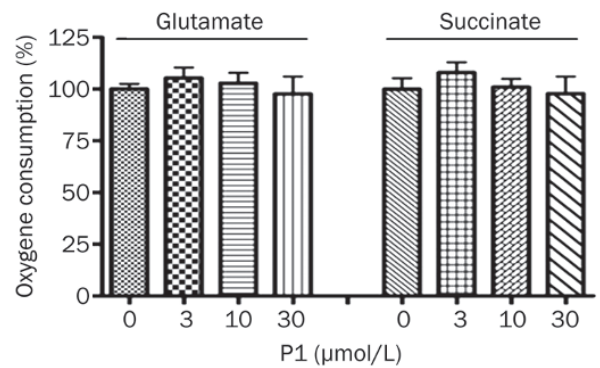

Antimycin

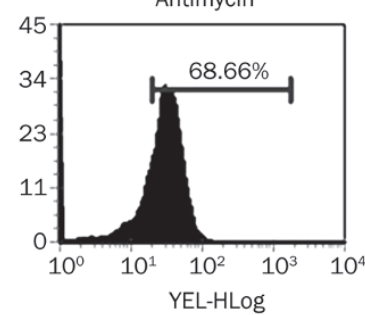

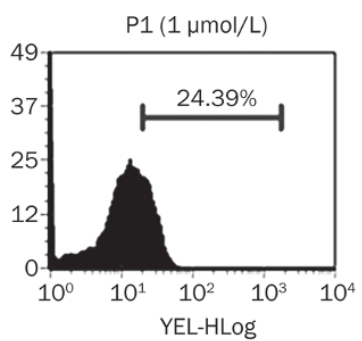

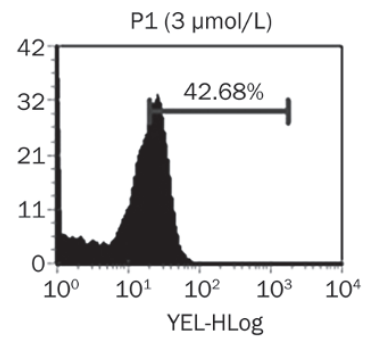

C

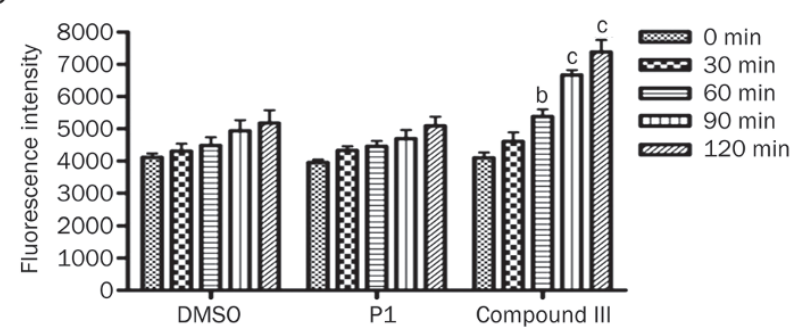

E

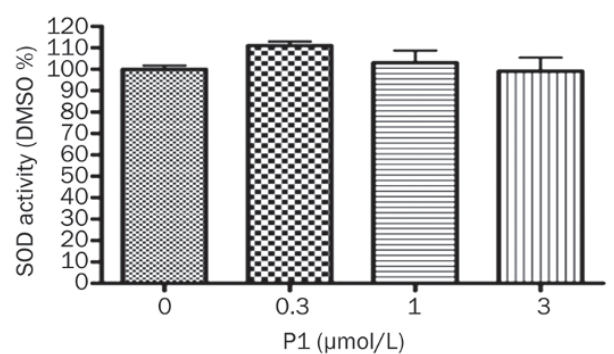

Figure 6. P1-induced mitochondrial ROS. (A) Mitochondrial ROS were measured using MitoSOX staining after treatment with $\mathrm{P} 1 \mathrm{or}$ antimycin (20 $\mu$ mol/L) for $3 \mathrm{~h}$. (B) MMP was measured using JC-1 staining after treatment with P1 or CCCP $(5 \mu \mathrm{mol} / \mathrm{L})$ for $1 \mathrm{~h}$. (C) The effect of $10 \mu \mathrm{mol} / \mathrm{L} P 1$ on free radical signal production in vitro. Compound III, a isoquinoline-1,3,4-trione derivative, was used as a positive control. (D) The effect of P1 on the respiration of isolated mitochondria from HeLa cells. The results are presented as fold-changes compared with the DMSO group. (E) SOD activity was measured after treatment with $\mathrm{P} 1$ for $3 \mathrm{~h}$. Mean \pm SD. $n=3 .{ }^{b} P<0.05,{ }^{\mathrm{c}} P<0.01$ vs the control.

trial indicated that this compound is safe to administer but has a low bioavailability owing to its extremely limited water solubility ${ }^{[24]}$. Therefore we examined the water solubility of P1 and found it to be $14 \mu \mathrm{mol} / \mathrm{L}$, whereas that of curcumin is 1.5 $\mu \mathrm{mol} / \mathrm{L}$.

Its antioxidant properties appear to be critical for the chemopreventive effects of curcumin, and it is well documented that, similar to most polyphenols, curcumin also acts as a pro-oxidant under certain conditions by producing ROS. However, this ROS production is not related to NF-KB inhibition ${ }^{[38-40]}$. Additionally, curcumin turmeric has other curcuminoids, such as demethoxycurcumin (DMC) and bisdemethoxycurcumin (BDMC). These three curcuminoids all exhibit comparable anti-proliferative effects. Curcumin is the most able to suppress TNF-induced NF-kB activation, followed by DMC and BDMC. In contrast, when pro-oxidant activity was examined, BDMC was maximally active at inducing ROS, whereas curcumin and DMC had minimal activity, suggesting that these compounds elicit anti-tumor activity through different mechanisms ${ }^{[41]}$. Nevertheless, the piperidin-4-one cur- cumin analog EF-24 has been shown to induce apoptosis by upregulating cellular antioxidant responses ${ }^{[42]}$. However, P1 exhibited a distinct mechanism; the generation of ROS played an important role in the inhibition of cell growth and NF-kB activation. Molecular oxygen is an essential molecule for all aerobic life forms, notably for the cell to obtain energy as a form of $\mathrm{ATP}^{[43]}$. Under normal or pathologic conditions, $\mathrm{O}_{2}$ is often transformed into highly reactive forms, called ROS, such as hydrogen peroxide $\left(\mathrm{H}_{2} \mathrm{O}_{2}\right)$, superoxide anions and hydroxyl radicals. Evidence from several areas has indicated that NF-KB is a redox-regulated transcription factor. It has been reported that ROS activates the NF-KB signaling pathway through ІкBa $Y 42^{[2]}$ phosphorylation and activation of RelA DNA-binding activity, etc. Furthermore, overexpression of superoxide dismutase ${ }^{[44]}$, the enzyme that converts superoxide anions to hydrogen peroxide, enhances the activation of NF-kB; overexpression of catalase ${ }^{[4]}$ and glutathione peroxidase ${ }^{[45]}$, enzymes that scavenge hydrogen peroxide and other organic peroxides, have been found to inhibit the cytokine induced activation of NF-KB. However, there is evidence that ROS may also inhibit 
A
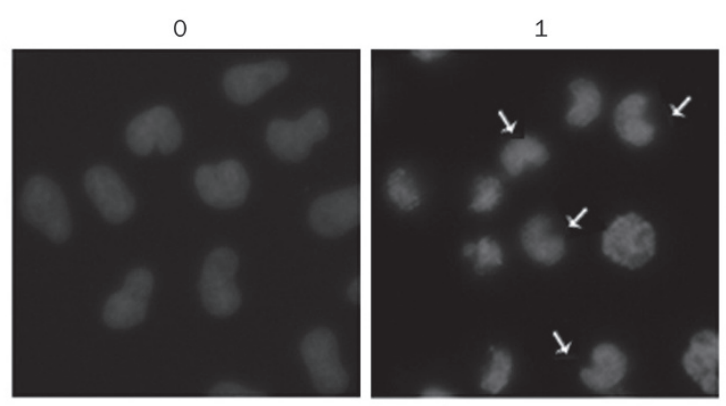

B
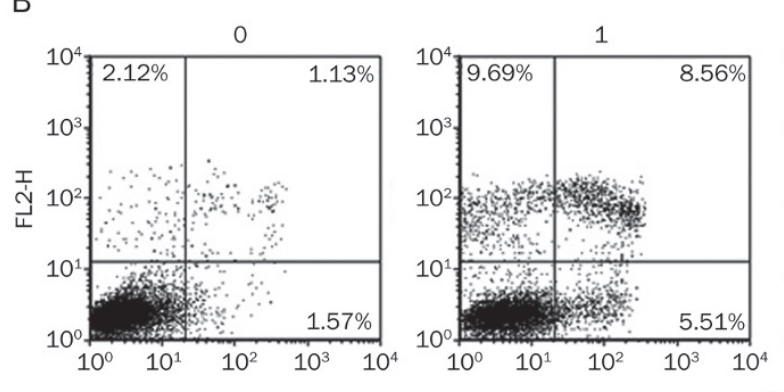

FL1-H
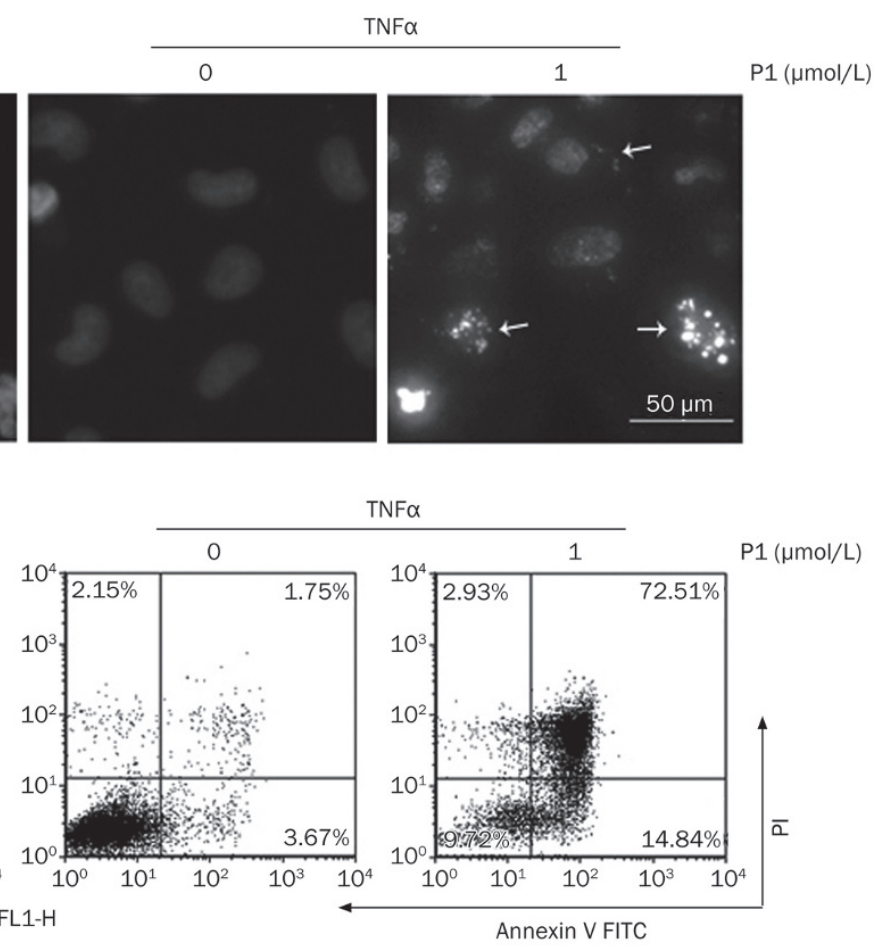

C

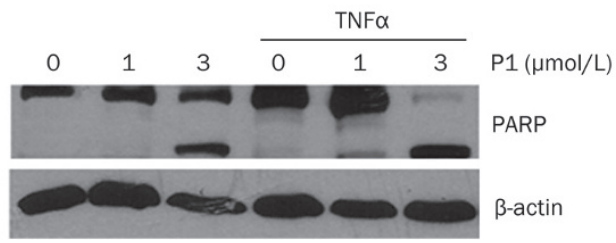

the NF- $\mathrm{kB}$ signaling pathway ${ }^{[46]}$. It has been reported that cysteine residue 179 in the activation loop of IKK- $\beta^{[47,48]}$ and that several conserved cysteine residues in the DNA-binding loop of the NF-kB/Rel proteins ${ }^{[49-51]}$ may be targeted by ROS. P1 may inhibit NF-KB activation by modifying Cys-179 of IKK- $\beta$, as the inhibitory effects of P1 on NF-KB activity were abolished by the expression of mutant IKK- $\beta$, which contains alanine at residue 179 rather than cysteine (Figure 5F).

ROS are generated in the cell through multiple sources, such as the electron transport chain in mitochondria, ionizing radiation and enzymes, such as phagocytic and non-phagocytic $\mathrm{NADPH}$ oxidases, lipoxygenases and cyclooxygenases that produce superoxide anions. Cells have developed antioxidant defenses, such as SOD-1, -2 , and -3 and catalase, glutathione peroxidases and peroxiredoxins ${ }^{[43]}$. The ROS induced by P1 was shown to originate from mitochondria, although P1 had no effect on mitochondrial respiratory complexes or SOD activity (Figure 6E, 6D), which suggested that P1 may affect electron donors or other ROS elimination systems or the phosphorylation system (ie, ATP synthase and adenine nucleotide exchanger).

It has been reported that TNF-a has multiple roles in cancer cells. TNF-a was able to induce apoptosis in cancer cells in vitro and in vivo ${ }^{[52]}$. However, tumor-secreted TNF-a may also be the crucial trigger for tumor recurrence and metas-
Figure 7. $\mathrm{P} 1$ stimulated apoptosis induced by TNF- $\alpha$. (A) DAPI staining of HeLa cells treated with TNF- $\alpha(10 \mathrm{ng} / \mathrm{mL})$ or P1 for $24 \mathrm{~h}$. (B) Annexin $V$ staining of HeLa cells treated with TNF- $\alpha(10 \mathrm{ng} / \mathrm{mL})$ or P1 for $24 \mathrm{~h}$. (C) PARP cleavage induced by P1 or TNF $\alpha(10 \mathrm{ng} / \mathrm{mL})$ in HeLa cells after treatment for $24 \mathrm{~h}$.

tasis. Many studies have shown that tumor-secreted TNF-a prevents cancer cell apoptosis mediated by exogenous TNF- $a$ by activating the NF-kB signaling pathway ${ }^{[10,34]}$. Furthermore, the apoptotic potency of TNF- $\alpha$ is increased in tumors when NF-KB activity is inhibited ${ }^{[10,34,53-57]}$. Therefore, the inhibition of NF-kB activation by pharmacological approaches has become an attractive strategy for improving the anti-tumor activity of TNF-a ${ }^{[7,8,34]}$. In the current study, we found that 1 $\mu \mathrm{mol} / \mathrm{L}$ P1 or TNF-a alone showed moderate pro-apoptotic activities in HeLa cells. However, $1 \mu \mathrm{mol} / \mathrm{L}$ P1 dramatically increased apoptosis in the presence of TNF- $\alpha$, suggesting a synergistic effect of P1 together with TNF- $\alpha$.

In summary, we identified a novel small molecule NF-kB signaling pathway inhibitor: P1, a curcumin analog. Our data demonstrated that P1 was more active than curcumin. The compound inhibited cancer cell proliferation, induced tumor cell apoptosis by increasing PARP-mediated apoptotic activation, and stimulated the anti-tumor activity of TNF-a. These results support the conclusion that P1 may be a promising new agent for the treatment of cancer. Interestingly, P1 exhibited a distinct mechanism; rather than anti-oxidation, $\mathrm{P} 1$ inhibited the NF-KB signaling pathway by inducing mitochondrial ROS and modifying C179 of IKK- $\beta$. The exact mechanism of ROS generation and the effect of P1 on mitochondrial function require further study. Clinical trials and animal experiments 
suggest that curcumin is quite safe but suffers from poor solubility and bioavailability. With its higher water solubility, P1 may exhibit better therapeutic effects. Further studies in animals and patients are required to further establish the anticancer effects of P1.

\section{Acknowledgements}

This work was supported by grants from the National Natural Science Foundation of China (№ 91029716, 81021062, and 81072667).

\section{Author contribution}

Yan-min PENG, Yu-bo ZHOU, and Jia LI designed the research; Yan-min PENG performed the research; and Jian-bin ZHENG contributed new reagents. Yan-min PENG and Jianbin ZHENG analyzed the data, and Yan-min PENG and Yu-bo ZHOU wrote the paper.

\section{References}

1 Baldwin AS Jr. The NF-kB and IkB proteins: new discoveries and insights. Annu Rev Immunol 1996; 14: 649-81.

2 Yakovlev VA, Barani IJ, Rabender CS, Stephen M, Leach JK, Graves $\mathrm{PR}$, et al. Tyrosine nitration of IkB $\alpha$ : a novel mechanism for NF-KB activation. Biochemistry 2007; 46: 11671-83.

3 Aggarwal BB, Takada Y, Oommen OV. From chemoprevention to chemotherapy: common targets and common goals. Expert Opin Investig Drugs 2004; 13: 1327-38.

4 Kumar A, Takada Y, Boriek AM, Aggarwal BB. Nuclear factor-kB: its role in health and disease. J Mol Med 2004; 82: 434-48.

5 Strnad J, Burke JR. IkB kinase inhibitors for treating autoimmune and inflammatory disorders: potential and challenges. Trends Pharmacol Sci 2007; 28: 142-8.

6 Bharti AC, Aggarwal BB. Nuclear factor-kappa B and cancer: its role in prevention and therapy. Biochem Pharmacol 2002; 64: 883-8.

7 Egberts JH, Cloosters V, Noack A, Schniewind B, Thon L, Klose S, et al. Anti-tumor necrosis factor therapy inhibits pancreatic tumor growth and metastasis. Cancer Res 2008; 68: 1443-50.

8 Lejeune FJ, Rüegg C, Liénard D. Clinical applications of TNF- $\alpha$ in cancer. Curr Opin Immunol 1998; 10: 573-80.

9 Flier JS, Underhill LH, Bazzoni F, Beutler B. The tumor necrosis factor ligand and receptor families. N Engl J Med 1996; 334: 1717-25.

10 Mocellin S, Pilati P, Nitti D. Towards the development of tumor necrosis factor (TNF) sensitizers: making TNF work against cancer. Curr Pharm Des 2007; 13: 537-51.

11 Ammon HP, Wahl MA. Pharmacology of curcuma longa. Planta Med 1991; 57: 1-7.

12 Lim GP, Chu T, Yang F, Beech W, Frautschy SA, Cole GM. The curry spice curcumin reduces oxidative damage and amyloid pathology in an Alzheimer transgenic mouse. J Neurosci 2001; 21: 8370-7.

13 Gukovsky I, Reyes CN, Vaquero EC, Gukovskaya AS, Pandol SJ. Curcumin ameliorates ethanol and nonethanol experimental pancreatitis. Am J Physiol Gastrointest Liver Physiol 2003; 284: G85-G95.

14 Huang MT, Lysz T, Ferraro T, Abidi TF, Laskin JD, Conney AH. Inhibitory effects of curcumin on in vitro lipoxygenase and cyclooxygenase activities in mouse epidermis. Cancer Res 1991; 51: 813-9.

15 Fiorucci S, Meli R, Bucci M, Cirino G. Dual inhibitors of cyclooxygenase and 5-lipoxygenase. A new avenue in anti-inflammatory therapy? Biochem Pharmacol 2001; 62: 1433-8.
16 Azuine MA, Bhide SV. Chemopreventive effect of turmeric against stomach and skin tumors induced by chemical carcinogens in Swiss mice. Nutr Cancer 1992; 17: 77-83.

17 Azuine MA, Bhide SV. Protective single/combined treatment with betel leaf and turmeric against methyl (acetoxymethyl) nitrosamineinduced hamster oral carcinogenesis. J Cancer Res Clin Oncol 1992; 51: 412-5.

18 Duvoix A, Blasius R, Delhalle S, Schnekenburger M, Morceau F, Henry $\mathrm{E}$, et al. Chemopreventive and therapeutic effects of curcumin. Cancer Lett 2005; 223: 181-90.

19 Shishodia S, Amin HM, Lai R, Aggarwal BB. Curcumin (diferuloylmethane) inhibits constitutive NF-[kappa] B activation, induces $G_{1} / S$ arrest, suppresses proliferation, and induces apoptosis in mantle cell lymphoma. Biochem Pharmacol 2005; 70: 700-13.

20 Shakibaei M, John T, Schulze-Tanzil G, Lehmann I, Mobasheri A. Suppression of NF-[kappa] B activation by curcumin leads to inhibition of expression of cyclo-oxygenase-2 and matrix metalloproteinase-9 in human articular chondrocytes: Implications for the treatment of osteoarthritis. Biochem Pharmacol 2007; 73: 1434-45.

21 Kudo C, Yamakoshi H, Sato A, Ohori H, Ishioka C, Iwabuchi Y, et al. Novel curcumin analogs, GO-Y030 and GO-Y078, are multi-targeted agents with enhanced abilities for multiple myeloma. Anticancer Res 2011; 31: 3719-26.

22 Mosley CA, Liotta DC, Snyder JP. Highly active anticancer curcumin analogues. Adv Exp Med Biol 2007; 595: 77-103.

23 Kunnumakkara AB, Guha S, Krishnan S, Diagaradjane P, Gelovani J, Aggarwal BB. Curcumin potentiates antitumor activity of gemcitabine in an orthotopic model of pancreatic cancer through suppression of proliferation, angiogenesis, and inhibition of nuclear factor-KB regulated gene products. Cancer Res 2007; 67: 3853-61.

24 Ohori H, Yamakoshi H, Tomizawa M, Shibuya M, Kakudo Y, Takahashi A, et al. Synthesis and biological analysis of new curcumin analogues bearing an enhanced potential for the medicinal treatment of cancer. Mol Cancer Ther 2006; 5: 2563-71.

25 Zang Y, Yu LF, Pang T, Fang LP, Feng X, Wen TQ, et al. AICAR induces astroglial differentiation of neural stem cells via activating the JAK/ STAT3 pathway independently of AMP-activated protein kinase. J Biol Chem 2008; 283: 6201-8.

26 Vichai V, Kirtikara K. Sulforhodamine B colorimetric assay for cytotoxicity screening. Nat Protoc 2006; 1: 1112-6.

27 Du JQ, Wu J, Zhang HJ, Zhang YH, Qiu BY, Wu F, et al. Isoquinoline-1, 3,4-trione derivatives inactivate caspase-3 by generation of reactive oxygen species. J Biol Chem 2008; 283: 30205-15.

28 Ito D, Seki M, Tsunoda Y, Uchiyama H, Suzuki N. Nuclear transport impairment of amyotrophic lateral sclerosis linked mutations in FUS/ TLS. Ann Neurol 2011; 69: 152-62.

29 Ogura A, Oowada S, Kon Y, Hirayama A, Yasui H, Meike S, et al. Redox regulation in radiation-induced cytochrome $c$ release from mitochondria of human lung carcinoma A549 cells. Cancer Lett 2009; 277: 64-71.

30 Yamamoto Y, Gaynor RB. Therapeutic potential of inhibition of the NFkappaB pathway in the treatment of inflammation and cancer. J Clin Invest 2001; 107: 135-42.

31 Kasinski AL, Du Y, Thomas SL, Zhao J, Sun SY, Khuri FR, et al. Inhibition of IKK-NF-KB signaling pathway by EF24, a novel monoketone analogue of curcumin. Mol Pharmacol 2008; 3: 654-61.

32 Sato A, Kudo C, Yamakoshi H, Uehara Y, Ohori H, Ishioka C, et al. Curcumin analog GO-Y030 is a novel inhibitor of IKK- $\beta$ that suppresses NF-KB signaling and induces apoptosis. Cancer Sci 2011; 102: 1045-51.

33 Ott M, Gogvadze V, Orrenius S, Zhivotovsky B. Mitochondria, oxidative 
stress and cell death. Apoptosis 2007; 12: 913-22.

34 Pilati P, Rossi CR, Mocellin S. Strategies to enhance the anticancer potential of TNF. Front Biosci 2008; 13: 3181-93.

35 Karin M, Yamamoto Y, Wang QM. The IKK NF-KB system: a treasure trove for drug development. Nat Rev Drug Discov 2004; 3: 17-26.

36 Sato A, Kudo C, Yamakoshi H, Uehara Y, Ohori H, Ishioka C, et al. The curcumin analog GO-YO3O is a novel inhibitor of IKK 3 that suppresses NF-KB signaling and induces apoptosis. Cancer Sci 2011; 102 : 1045-51.

37 Kasinski AL, Du Y, Thomas SL, Zhao J, Sun SY, Khuri Fr, et al. Inhibition of IKK-NF-KB signaling pathway by EF24, a novel monoketone analogue of curcumin. Mol Pharmacol 2008; 3: 654-61.

38 Bhaumik S, Anjum R, Rangaraj N, Pardhasaradhi BVV, Khar A. Curcumin mediated apoptosis in AK-5 tumor cells involves the production of reactive oxygen intermediates. FEBS Lett 1999; 456: 311-4.

39 Galati G, Sabzevari O, Wilson JX, O'Brien PJ. Prooxidant activity and cellular effects of the phenoxyl radicals of dietary flavonoids and other polyphenolics. Toxicology 2002; 177: 91-104.

40 Javvadi P, Segan AT, Tuttle SW, Koumenis C. The chemopreventive agent curcumin is a potent radiosensitizer of human cervical tumor cells via increased reactive oxygen species production and overactivation of the mitogen-activated protein kinase pathway. Mol Pharmacol 2008; 73: 1491-501.

41 Singh U, Barik A, Singh BG, Priyadarsini KI. Reactions of reactive oxygen species (ROS) with curcumin analogues: structure-activity relationship. Free Radic Res 2011: 3: 1-9.

42 Tan X, Sidell N, Mancini A, Huang RP, Wang S, Horowitz IR, et al. Multiple anticancer activities of ef24, a novel curcumin analog, on human ovarian carcinoma cells. Reprod Sci 2010; 17: 931-40.

43 Gloire G, Legrand-Poels S, Piette J. NF-[kappa] B activation by reactive oxygen species: fifteen years later. Biochem pharmacol 2006; 72 : 1493-505.

44 Schmidt KN, Amstad P, Cerutti P, Baeuerle PA. Identification of hydrogen peroxide as the relevant messenger in the activation pathway of transcription factor NF-kappaB. Adv Exp Med Biol 1996; 387 : 63-8.

45 Staal FJ, Roederer M, Herzenberg LA. Intracellular thiols regulate activation of nuclear factor kappa $B$ and transcription of human immunodeficiency virus. Proc Natl Acad Sci U S A 1990; 87: 9943-7.

46 Loukili N, Rosenblatt-Velin N, Rolli J, Levrand S, Feihl F, Waeber B, et al. Oxidants positively or negatively regulate nuclear factor $\mathrm{KB}$ in a context-dependent manner. J Biol Chem 2010; 285: 15746-52.
47 Song YS, Lee YS, Chan PH. Oxidative stress transiently decreases the IKK complex (IKK $\alpha, \beta$, and $\gamma$ ), an upstream component of NF-KB signaling, after transient focal cerebral ischemia in mice. J Cereb Blood Flow Metab 2005; 25: 1301-11.

48 Zhang $\mathrm{Y}$, Chen F. Reactive oxygen species (ROS), troublemakers between nuclear factor-KB (NF-KB) and c-Jun NH2-terminal kinase (JNK). Cancer Res 2004; 64: 1902.

49 Matthews JR, Kaszubska W, Turcatti G, Wells TNC, Hay RT. Role of cysteine62 in DNA recognition by the P50 subunit of NF-KB. Nucleic Acids Res 1993; 21: 1727.

50 Matthews JR, Wakasugi N, Virelizier JL, Yodoi J, Hay RT. Thioredoxin regulates the DNA binding activity of NF-kappa $B$ by reduction of a disulphide bond involving cysteine 62. Nucleic Acids Res 1992; 20 : 3821-30.

51 Tjalkens RB, Luckey SW, Kroll DJ, Petersen DR. [alpha],[beta]Unsaturated aldehydes increase glutathione s-transferase mRNA and protein: Correlation with activation of the antioxidant response element. Arch Biochem Biophys 1998; 359: 42-50.

52 Van Antwerp DJ, Martin SJ, Kafri T, Green DR, Verma IM. Suppression of TNF- $\alpha$-induced apoptosis by NF-KB. Science 1996; 274: 787-9.

53 Koliopanos A, Avgerinos C, Paraskeva C, Touloumis Z, Kelgiorgi D, Dervenis C. Molecular aspects of carcinogenesis in pancreatic cancer. Hepatobiliary Pancreat Dis Int 2008; 7: 345-56.

54 Sung B, Pandey MK, Ahn KS, Yi T, Chaturvedi MM, Liu M, et al. Anacardic acid (6-nonadecyl salicylic acid), an inhibitor of histone acetyltransferase, suppresses expression of nuclear factor-kB regulated gene products involved in cell survival, proliferation, invasion, and inflammation through inhibition of the inhibitory subunit of nuclear factor-kB $\alpha$ kinase, leading to potentiation of apoptosis. Blood 2008; 111: 4880-91.

55 Vince JE, Wong W, Khan N, Feltham R, Chau D, Ahmed AU, et al. IAP antagonists target cIAP1 to induce TNF [alpha]-dependent apoptosis. Cell 2007; 131: 682-93.

56 Zhang Y, Gavriil M, Lucas J, Mandiyan S, Follettie M, Diesl V, et al. IKB $\alpha$ kinase inhibitor IKI-1 conferred tumor necrosis factor a sensitivity to pancreatic cancer cells and a xenograft tumor model. Cancer Res 2008; 68: 9519-24.

57 Takada Y, Ichikawa H, Badmaev V, Aggarwal BB. Acetyl-11-keto- $\beta$ boswellic acid potentiates apoptosis, inhibits invasion, and abolishes osteoclastogenesis by suppressing NF-KB and NF-KB-regulated gene expression. J Immunol 2006; 176: 3127-40. 